EISSN: 2706-7955 ISSN: 2077-4605

DOI: $10.36632 /$ mejar/2021.10.1.25

Journal homepage: www.curresweb.com

Pages: 391-399

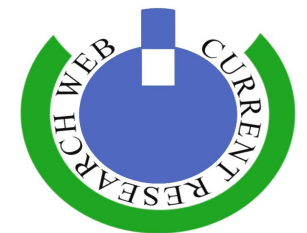

\title{
Effect of Irrigation Intervals and Sodium Selenite on Growth, Seed Yield and Essential Oil of Fennel
}

\author{
Esam A. A. Al-Azzony ${ }^{1}$ and Rania M.R. Khater ${ }^{2}$ \\ ${ }^{1}$ Medicinal and Aromatic Plants Department, Agriculture Research Center, Cairo, Egypt. \\ ${ }^{2}$ Medicinal and Aromatic Plants Department, Desert Research Center, Cairo, Egypt. \\ Received: 20 January $2021 \quad$ Accepted: 18 March $2021 \quad$ Published: 25 March 2021
}

\begin{abstract}
This trial was conducted at Balouza Research Station, Desert Research Center, North Sinai, Egypt during 2018 and 2019 seasons on fennel.The effects of irrigation intervals, sodium selenate (source of $\mathrm{Se})$ and their interactions on growth, seed yield and essential oil of bitter fennel plant were investigated. Irrigation intervals were every 4,6 and 8 days, while the levels of sodium selenate were $0,10,20$ and $30 \mathrm{mg} / \mathrm{L}$. Pl ants irrigated every 6 days and sprayed with $30 \mathrm{mg} / \mathrm{L}$ (sodium selenate) gave the highest values of plant height, number of umbels / plant, seed yield, NPK and essential oil contents.
\end{abstract}

Keywords: irrigation intervals, sodium selenite, fennel, Foeniculum vulgare

\section{Introduction}

Fennel (Foeniculum vulgare), belongs to Apiaceae family, is an important aromatic plant due to its uses in medicine and foods. It is widely cultivated, throughout the temperate and tropical regions of the world due to the nutritional value of their seeds (Diao et al., 2014). Which have emerged as a source of health beneficial compounds including minerals, vitamins and essential oils which explain their applications for pharmaceutical and food industries (Nassar, et al., 2010). The cultivation of medicinal and aromatic plants has increased significantly in recent decades to meet the demand of the increased population and to avoid side effects of chemicals on human health. Moreover, medicinal plants are more profitable to growers as compared to many other traditional crops. Because of its flavour, fennel is cultivated in Mediterranean countries, including Egypt, where it is cultivated mainly in the north upper governors such as Minya, Fayoum, BeniSuef, and Assiut. The essential oil is used as flavoring agent, carminative, diuretic, antispasmodic, stomachic, expectorant, and aromatic (Cioanca et al., 2016). Also, it was reported that fennel seed possesses anticancer activity (Anand et al., 2008).

Drought is a major environmental stress that affects plant morphology, physiology and biochemistry, causing a significant reduction in agricultural production. Although the effects of drought on many plants have been widely investigated, less is known about the biosynthesis and accumulation of essential oil in aromatic plants under water deficit conditions (Sangwan et al., 1993). Growth and essential oil content of fennel plants can be affected by irrigation schedules (Patel et al., 2000). Letchamo et al., (1995) found that there was a significant reduction in dry matter and relative growth rate of Thymus vulgaris grown under drought stress. Cymbopogon nardus var. confertiflorus and C. pendulus were exposed to water stress; results indicated that water deficit reduced plant height, leaf length, leaf area, fresh and dry weight, and moisture content (Sangwan et al., 1994). Essential oil content was significantly affected depending on the water stress level. Origanum majorana had higher values of essential oil under water stress treatments compared with control (Rhizopoulou and Diamantoglou, 1991).

Selenium (Se) is a beneficial element for higher plants and has a positive effect and performance on plants growth. It plays an important role in enhancing the resistance of plants to certain abiotic stresses. The protective role of low selenium concentrations in plants exposed to stress conditions has

Corresponding Author: Esam A. A. Al-Azzony, Medicinal and Aromatic Plants Department, Agriculture Research Center, Cairo, Egypt. 
been attributed to various defense mechanisms which can stimulate plant growth (Hajiboland and Keivanfar, 2012).

The aim of this study evaluate the irrigation intervals and spraying with sodium selenate on the vegetative growth, oil production and seed yield of fennel plants under North Sinai conditions.

\section{Material and Method}

The study was conducted at Balouza Research Station, Desert Research Center, North Sinai during 2018 and 2019 seasons on fennel plants. to study the effect of irrigation rates and spraying with selenium and interaction between them on vegetative growth, seed production and volatile essential oil of fennel plant under North Sinai conditions.

The seeds of fennel plant were obtained from the Medicinal and Aromatic Plants Research Department, Horticulture Institute, Agricultural Research Center, Dokki, Egypt. The seeds were sown on October $12^{\text {th }}$ in both seasons. The distance between rows was $50 \mathrm{~cm}$ and between plants within row was $30 \mathrm{~cm}$. Seedlings were thinned to one plant per hill. The irrigation system of the experiment was drip irrigation with the rate of $4 \mathrm{l} / \mathrm{h}$. All plants received normal agricultural practices if needed. The experimental soil was sandy in texture "sand $90 \%$, silt $5 \%$ and clay $5 \%$ " and chemical properties were: available N, P and K 60,365 and144 ppm, Soluble ions (meq/l) Cations $\left(\mathrm{Ca}^{+2} \mathrm{Mg}^{+2} \mathrm{Na}^{+1}\right.$ and $\mathrm{K}^{+1} 1.8$, 2.1, 1.5 and 0.09 ) and Anions $\left(\mathrm{HCO}_{3}, \mathrm{SO}_{4}\right.$ and $\mathrm{Cl}^{-1} 3.5,0.84$ and 1.51) respectively; $\mathrm{pH} 7.75$ and EC. $395 \mathrm{Mmhos} / \mathrm{cm}$. according to Page et al. (1984).

The chemical fertilizer recommended rates for Foeniculum vulgare plant are $150 \mathrm{~kg}$ ammonium sulphate $(20.5 \% \mathrm{~N})$ per feddan $\left(4200 \mathrm{~m}^{2}\right)$ and $75 \mathrm{~kg}$ potassium sulphate $\left(48 \% \mathrm{~K}_{2} \mathrm{O}\right)$ per feddan divided into three equal sections and added every two months from planting and $300 \mathrm{~kg}$ calcium superphosphate per feddan was added during soil preparation.

This experiment included 12 treatments, which were the interaction of three levels of irrigation intervals; i.e. 4, 6, 8 days and four levels of sodium selenate (source of Se) $0,10,20$ and $30 \mathrm{mg} / \mathrm{l}$. The treatments were arranged in a split plot design with three replicates. The irrigation intervals were randomly arranged in the main plots and the Sodium selenite concentrations were randomly distributed in the sub-plots. The plants are applied with Sodium selenite concentrations three times; after 30,60 and 90 days from planting as foliar spray. As for the control treatment (spray without selenium) it was sprayed with distilled water.

\subsection{Plant growth and yield characteristics}

Plant height (cm), number of umbels / plant and seed yield ( $\mathrm{g} / \mathrm{plant})$ and $\mathrm{kg} / \mathrm{fed}$ ) were recorded.

\subsection{Essential oil isolation}

Essential oil percentage of the fruits was determined according to British Pharmacopoeia, (1963), Essential oil (liter/fed.) was calculated according to fruit yield. GC analysis of volatile oil of each treatment. The chromatograph apparatus was fitted with a capillary column (BPX-5), and a 5\% phenyl (reqiv.) polysillphenylene-siloxan $(30 \mathrm{~m} \times 0.25 \mathrm{~mm} \mathrm{ID} \times 0.25 \mu \mathrm{m})$ film. Temperature program ramp was increased at the rate of $80^{\circ} \mathrm{C} / \mathrm{min}$ from 70 to $200^{\circ} \mathrm{C}$. The flow rates of nitrogen, hydrogen and air were 1,30 and $330 \mathrm{ml} / \mathrm{min}$, respectively. The detector and injector temperatures were $300^{\circ} \mathrm{C}$ and $250^{\circ}$ $\mathrm{C}$, respectively.

\subsection{NPK determinations (in seeds)}

Mineral content included, nitrogen percentage using kjeldhal method described by Hach et al. (1985), phosphorus percentage was estimated according to A.O.A.C., (1970) and potassium percentage was determined by flame photometer using the method described by Brown and Lilleland, (1946).

\subsection{Statistical analysis}

Data recorded on growth, oil content and oil yield were statistically analysed, and separation of means was performed using the Least Significant Difference (L.S.D.) test at the 5\% level, as described by Little and Hills (1978). 


\section{Results and Discussion}

Data of both seasons (Table 1) show that plant height and umbel number were significantly affected by irrigation interval in both seasons, irrigation interval 6 days gave the tallest plants, with mean heights of 129.01 and $134.93 \mathrm{~cm}$ and highest number of umbels with mean values 69.16 and 72.83 in the first and second seasons, respectively. Spraying plants with Se resulted in significant increases of plant height and number of umbels in both seasons, the highest mean values of plant height and number of umbels were recorded with Se at rate $30 \mathrm{mg} / \mathrm{L}$. Regarding the interaction between the effects of irrigation interval and Se on plant height and umbels number, the data presented in Table (1) show that irrigation interval 6 days and spraying with Se at $30 \mathrm{mg} / \mathrm{L}$ gave the tallest plants with the values of 151.7 and $161.33 \mathrm{~cm}$, as well as the highest values of number of umbels/plant with values of 88 and 92.66 during both seasons.

Table 1: Effect of Irrigation Interval, Se and their interactions on plant height and number of umbels.

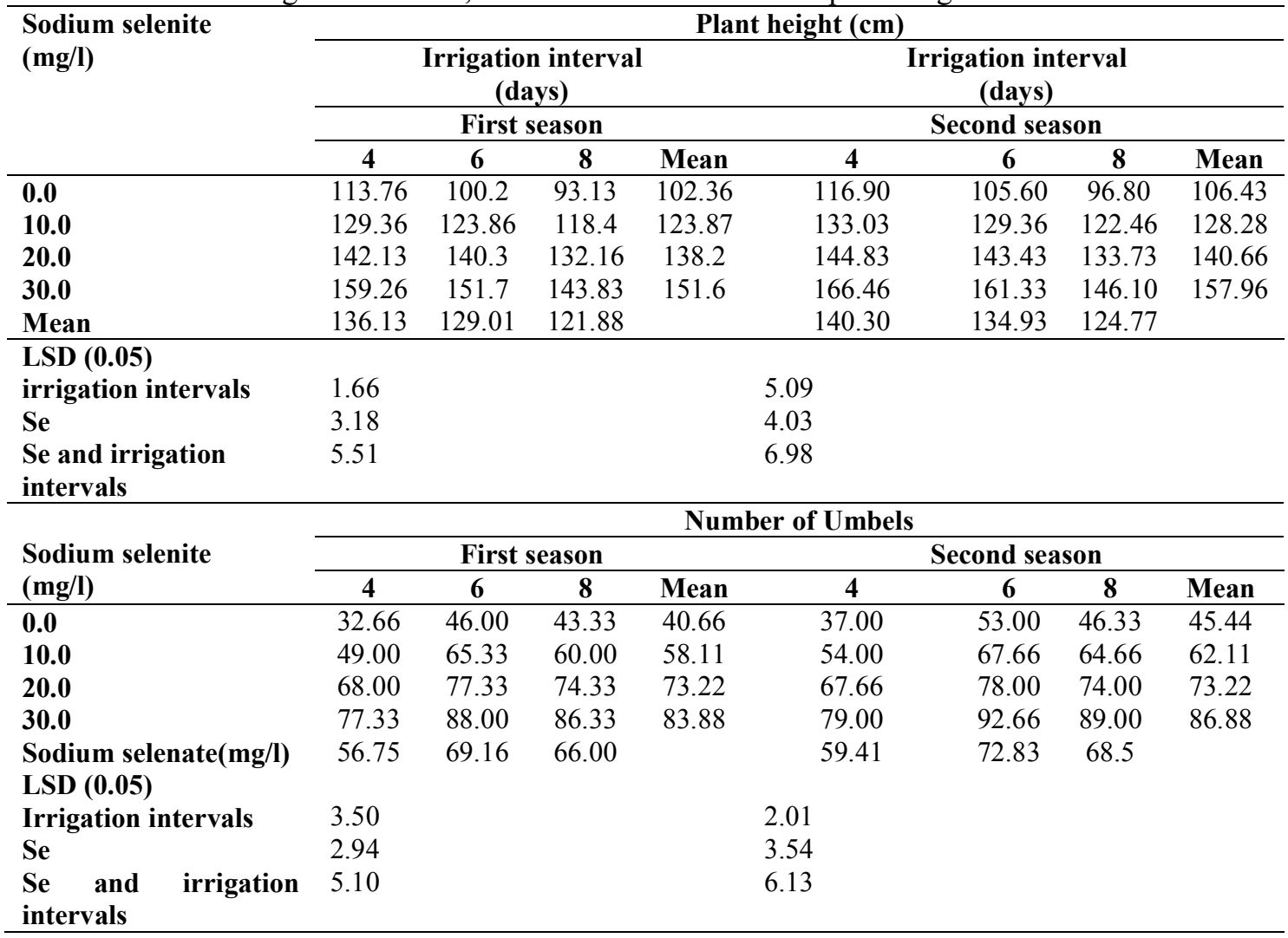

The Maximum seed yield was produced when the plants irrigated every 6 or 8 days. The difference between seeds yields resulting from these two treatments was insignificant. Application of $\mathrm{Se}$ at $30 \mathrm{mg} / \mathrm{L}$ produced higher seeds yield/plant, than the doses. Regarding the interaction between the effects of irrigation interval and Se on seed yield/plant: data presented in Table (2) show that significant differences were recorded between seed yield of plants treated with various combinations of two factors. In both seasons, the highest seed yields/plant (46.20 and $45.06 \mathrm{~g} / \mathrm{plant})$ were recoded with the plants irrigated every 6 days and sprayed by Se at $30 \mathrm{mg} / \mathrm{L}$.

Data presented in Table (2) show that seed yield $(\mathrm{kg} / \mathrm{fed})$ was affected by irrigation interval. In both season, the highest seed yields (708.3 and $686.19 \mathrm{~kg} / \mathrm{fed}$.) were produced as a result of using irrigation interval 6 days, followed by irrigation intervals which gave mean seed yields of 671.85 and $673.72 \mathrm{~kg} / \mathrm{fed}$. in the first and second seasons, respectively. On the other hand, the irrigation interval 4days gave the lowest seed yields in both seasons, with mean values 532.2 and $612.55 \mathrm{~kg} / \mathrm{fed}$. in the two seasons, respectively. Data in Table (2) also reveal that in most cases, the different levels of Se resulted in significant increases of fruits yield ( $\mathrm{kg} /$ fed.) compared control. The favorable effect of Se on 
seed yield was particularly evident at the highest application rate $(30 \mathrm{mg} / \mathrm{l})$, which gave higher seed yields (769.2 and $785.2 \mathrm{~kg} / \mathrm{fed}$.) than any other treatments.

Also, Regarding the interaction between the effects of irrigation interval and Se on seed yield/fed, plants irrigated every 6 days and sprayed by Se at $30 \mathrm{mg} / \mathrm{l}$. gave the highest seed yield/fed. with values of 831.6 and $801.6 \mathrm{~kg} / \mathrm{fed}$. in the first and second seasons, respectively).

Table 2: Effect of Irrigation Interval and Selenium on fruits yield of fennel.

\begin{tabular}{|c|c|c|c|c|c|c|c|c|}
\hline \multirow{3}{*}{$\begin{array}{l}\text { Sodium selenite } \\
(\mathrm{mg} / \mathrm{l})\end{array}$} & \multicolumn{8}{|c|}{ Seeds yield plant $^{-1}(\mathrm{~g})$} \\
\hline & \multicolumn{4}{|c|}{ First season } & \multicolumn{4}{|c|}{ Second season } \\
\hline & 4 & 6 & 8 & Mean & 4 & 6 & 8 & Mean \\
\hline 0.0 & 22.86 & 31.20 & 28.00 & 27.35 & 25.72 & 27.25 & 29.32 & 27.43 \\
\hline 10.0 & 27.03 & 36.46 & 34.60 & 32.70 & 32.46 & 34.63 & 36.83 & 34.64 \\
\hline 20.0 & 31.10 & 43.53 & 41.96 & 38.86 & 34.36 & 41.80 & 42.76 & 39.64 \\
\hline 30.0 & 37.26 & 46.20 & 44.73 & 42.73 & 43.56 & 45.06 & 44.53 & 44.38 \\
\hline Mean & 29.56 & 39.35 & 37.32 & & 34.03 & 37.18 & 38.36 & \\
\hline \multicolumn{9}{|l|}{ LSD (0.05) } \\
\hline irrigation intervals & 2.64 & & & & \multicolumn{4}{|l|}{2.08} \\
\hline $\mathrm{Se}^{\circ}$ & 2.07 & & & & \multicolumn{4}{|l|}{2.74} \\
\hline $\begin{array}{l}\text { Se and irrigation } \\
\text { intervals }\end{array}$ & 3.59 & & & & \multicolumn{4}{|l|}{4.75} \\
\hline \multirow{3}{*}{$\begin{array}{l}\text { Sodium } \\
\text { selenate(mg/l) }\end{array}$} & \multicolumn{8}{|c|}{ Seeds yield fed $^{-1}(\mathrm{~g})$} \\
\hline & \multicolumn{4}{|c|}{ First season } & \multicolumn{4}{|c|}{ Second season } \\
\hline & 4 & 6 & 8 & Mean & 4 & 6 & 8 & Mean \\
\hline 0.0 & 411.6 & 561.6 & 504 & 492.4 & 463.02 & 527.76 & 490.5 & 493.76 \\
\hline 10.0 & 486.6 & 656.4 & 622.8 & 588.6 & 584.4 & 663 & 811.2 & 686.2 \\
\hline 20.0 & 559.8 & 783.6 & 755.4 & 699.6 & 618.6 & 752.4 & 623.4 & 664.8 \\
\hline 30.0 & 670.8 & 831.6 & 805.2 & 769.2 & 784.2 & 801.6 & 769.8 & 785.2 \\
\hline Mean & 532.2 & 708.3 & 671.85 & & 612.55 & 686.19 & 673.72 & \\
\hline \multicolumn{9}{|l|}{ LSD (0.05) } \\
\hline irrigation intervals & 47.56 & & & & 37.52 & & & \\
\hline Se & 37.32 & & & & 49.38 & & & \\
\hline $\begin{array}{l}\text { Se and irrigation } \\
\text { intervals }\end{array}$ & 64.65 & & & & 85.52 & & & \\
\hline
\end{tabular}

Data in Table (3) revealed that the highest percentage of essential oil was obtained from the plants irrigated every 8 days with mean values of 1.50 and $1.62 \%$, followed by the plants irrigated every 6 days with mean values of 1.45 and $1.44 \%$. The lowest percentage was noticed with the plants irrigated every 4 days with mean values of 1.32 and $1.28 \%$ in both seasons. The favourable effect of Se on essential oil percentage was particularly evident at the highest application rate $(30 \mathrm{mg} / \mathrm{l})$, which gave higher oil percentage (1.52 and $1.57 \%$ ) than other treatments.

Regarding the interaction between the effects of irrigation interval and Se on the essential oil percentage; data presented in Table (3) show that significant differences were recorded between the essential oil percentages in plants treated with various combination of both factors. In both seasons, the highest essential oil percentages (1.60 and $1.71 \%$ ) were obtained from the plants irrigated every 8 days and sprayed with Se at $30 \mathrm{mg} / \mathrm{l}$.

Recorded data in Table (3) indicated that the maximum essential oil yield was produced from plants irrigated every 6 and 8 days. The differences in essential yields were insignificant. Application of Se at rate $30 \mathrm{mg} / 1$ produced higher essential oil yield than treatments.

Regarding the interactions between the effects of irrigation interval and Se on essential oil yield, plants irrigated every 6 days and sprayed by Se at rate $30 \mathrm{mg} / \mathrm{l}$. gave the highest essential oil yield. with values of 0.74 and $0.76 \mathrm{ml} /$ plant in the first and second seasons, respectively. Also, same treatment gave highest essential oil yield /fed. with mean values of 12.78 and $13.68 \mathrm{l} / \mathrm{fed}$. 
Table 3: Effect of Irrigation Interval and Selenium on oil content, oil yield/plant and oil yield per fed., of fennel plants.

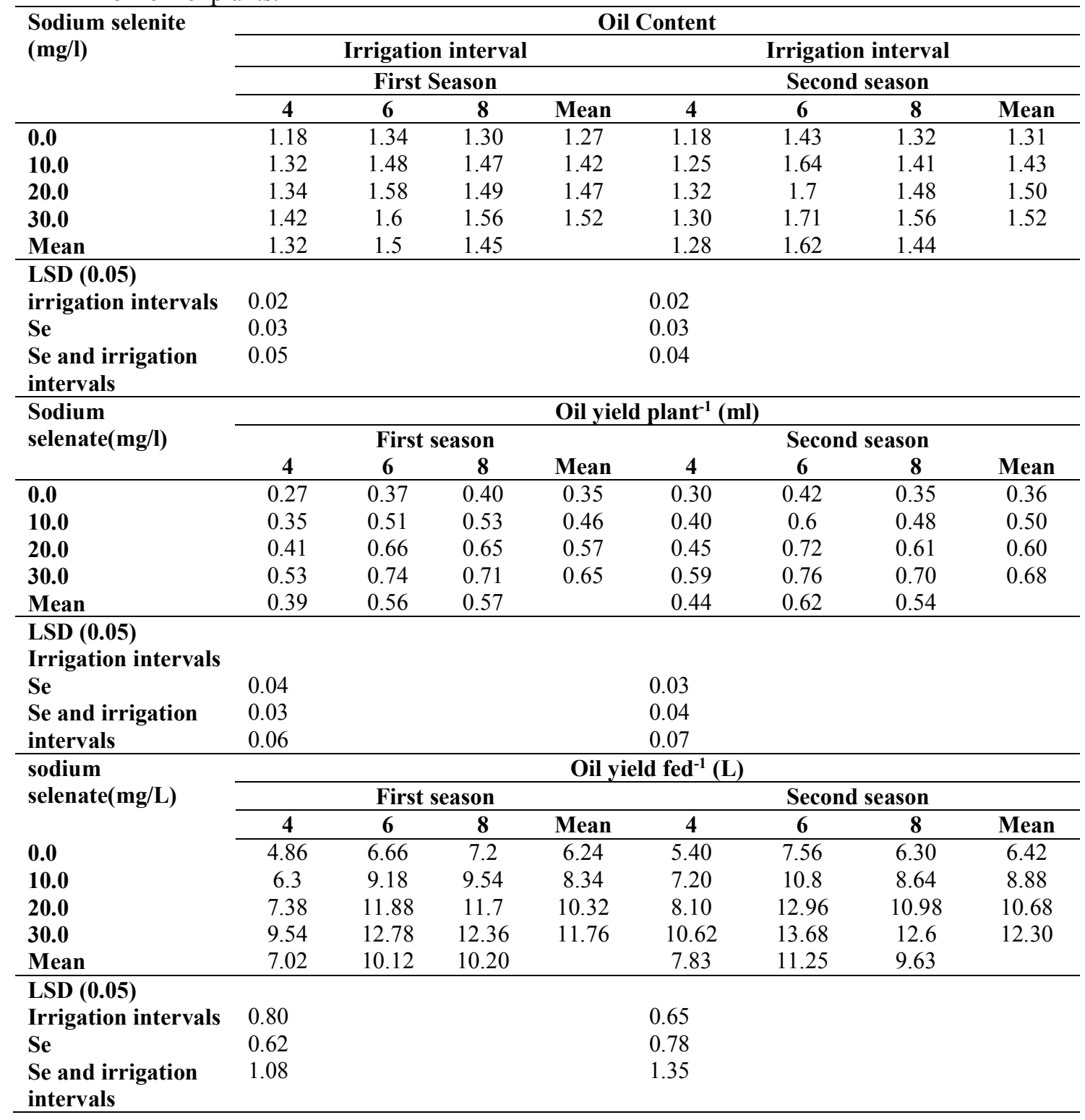

\subsection{Chemical composition of the essential oils}

Data in Table (4) showed the major idehtified components of fennel essential oil such as methyl chavicol (estragole), limonene, 1.8 cineole, fenchone, anethole, $\alpha$-pinene and myrcene. The amounts of methyl chavicol (estragole) were affected by irrigation interval and Se treatments; whereas the fertilization with irrigation interval 6 days and selenium at rate $30 \mathrm{mg}$ recorded the highest estragole $\%$ $(82.720 \%$ ), followed irrigation intervals 6 days and selenium at rate $20 \mathrm{mg}$ (which gave a mean esteragole content of $81.587 \%$ ), whereas the lowest content $(70.120 \%)$ was obtained from irrigation interval 8 days and selenium at rate $10 \mathrm{mg}$.

The changes in the components quality occurred by using different irrigation intervals and selenium rates may be due to their effect on the metabolism and on these enzymes responsible for the components synthesis. Also, some variations may be due to the different climatic factors, handling collection and ripening times. These results are in harmony with those of Ormeno et al., (2007) and Blanch et al., (2009) on Pinus halepensis. 
Table 4: Effect irrigation intervals and selenium on essential oil components of Foeniculum vulgars Mill. plants.

\begin{tabular}{|c|c|c|c|c|}
\hline \multirow[t]{2}{*}{$\begin{array}{l}\text { Sodium selenite } \\
(\mathrm{mg} / \mathrm{l})\end{array}$} & \multicolumn{2}{|c|}{$\begin{array}{c}\text { The components (\%) of the essential } \\
\text { oil }\end{array}$} & \multicolumn{2}{|c|}{ Irrigation Interval } \\
\hline & 4 & 6 & 8 & Means (Si) \\
\hline \multicolumn{5}{|c|}{$\alpha-$ Pinene } \\
\hline 0.0 & 0.976 & 1.466 & 1.300 & 1.247 \\
\hline 10.0 & 1.319 & 1.444 & 1.587 & 1.450 \\
\hline 20.0 & 1.289 & 1.203 & 1.679 & 1.390 \\
\hline 30.0 & 1.858 & 1.465 & 1.412 & 1.578 \\
\hline Means (Ir.) & 1.361 & 1.395 & 1.495 & \\
\hline \multicolumn{5}{|c|}{ Myrcene } \\
\hline 0.0 & 0.283 & 0.723 & 0.476 & 0.494 \\
\hline 10.0 & 0.109 & 0.818 & 0.466 & 0.464 \\
\hline 20.0 & 0.619 & 0.873 & 0.451 & 0.648 \\
\hline 30.0 & 0.66 & 0.449 & 0.416 & 0.508 \\
\hline Means (Ir.) & 0.418 & 0.716 & 0.452 & \\
\hline \multicolumn{5}{|c|}{ Fenchone } \\
\hline 0.0 & 0.696 & 1.169 & 0.500 & 0.788 \\
\hline 10.0 & 1.172 & 0.985 & 0.378 & 0.845 \\
\hline 20.0 & 0.700 & 0.883 & 0.492 & 0.691 \\
\hline 30.0 & 0.662 & 0.425 & 0.559 & 0.540 \\
\hline Means (Ir.) & 0.807 & 0.865 & 0.482 & \\
\hline \multicolumn{5}{|c|}{ Limonene } \\
\hline 0.0 & 10.78 & 11.01 & 10.555 & 10.781 \\
\hline 10.0 & 11.062 & 15.65 & 15.335 & 14.015 \\
\hline 20.0 & 9.092 & 8.613 & 12.529 & 10.078 \\
\hline 30.0 & 8.401 & 6.289 & 14.874 & 9.854 \\
\hline Means (Ir.) & 9.833 & 10.390 & 13.323 & \\
\hline \multicolumn{5}{|c|}{ 1,8 Cineol } \\
\hline 0.0 & 6.347 & 2.665 & 2.362 & 3.791 \\
\hline 10.0 & 4.261 & 1.674 & 6.895 & 4.276 \\
\hline 20.0 & 4.58 & 2.726 & 2.019 & 3.108 \\
\hline 30.0 & 2.478 & 4.986 & 4.819 & 4.094 \\
\hline Means (Ir.) & 4.416 & 3.012 & 4.023 & \\
\hline \multicolumn{5}{|c|}{ Methylchavicol (Estragole) } \\
\hline 0.0 & 73.902 & 75.975 & 71.019 & 73.632 \\
\hline 10.0 & 75.530 & 74.813 & 70.120 & 73.487 \\
\hline 20.0 & 79.578 & 81.587 & 73.947 & 78.370 \\
\hline 30.0 & 79.278 & 82.720 & 74.793 & 78.930 \\
\hline Means (Ir.) & 77.072 & 78.77375 & 72.46975 & \\
\hline \multicolumn{5}{|c|}{ Anethole } \\
\hline 0.0 & 0.162 & 0.218 & 1.981 & 0.787 \\
\hline 10.0 & 0.636 & 0.480 & 1.757 & 0.957 \\
\hline 20.0 & 0.218 & 0.315 & 1.956 & 0.829 \\
\hline 30.0 & 0.190 & 0.251 & 0.764 & 0.401 \\
\hline Means (Ir.) & 0.3015 & 0.316 & 1.6145 & \\
\hline
\end{tabular}

\subsection{Chemical analysis}

\subsection{1. $N, P$ and $K$ percentages}

Data Presented in Table (5) clearly illustrated that the mean values of the three major elements were affected by irrigation intervals, where the highest mean values were recorded under irrigation intervals 6 days in the two seasons and the mean values are 3.21, 3.13 and $0.34,0.36$ and 2.60 and $2.66 \%$ for $\mathrm{N}, \mathrm{P}$ and $\mathrm{K}$ in the first and second growing seasons, respectively. Increasing the mean values for the three studied elements $(\mathrm{N}, \mathrm{P}$ and $\mathrm{K})$ under irrigation interval 6 days. These results are in conformity with the findings of Patel et al., (2000) and (Yadav et al., 2000) on Foeniculum vulgare.

Data in the same Table showed that the mean values of N, P and $\mathrm{K}$ were clearly affected by spraying with selenium, where the highest values were recorded under the highest rate of selenium at rate $30 \mathrm{mg}$. 
On the contrary, the lowest values were recorded under control (without selenium) in the two growing seasons. These results are in agreement with those obtained by Boghdady et al., (2017) found that foliar spraying with selenium had a positive effect on a significant increase of $\mathrm{N}, \mathrm{P}$ and $\mathrm{K}$ percentage in faba bean seeds. Regarding the interaction between the effects of irrigation intervals and selenium rates on the N, P and K content, the data presented in Table (5) show that the highest N, P and K content (3.47, $3.68 \%$ and $0.42,0.41 \%$ and $2.72,3.14 \%$ in the first and second seasons, respectively) were recorded with irrigation interval 6 days and selenium at rate $30 \mathrm{mg}$.

Table 5: Effect of irrigation intervals and selenium rates on N, P and $\mathrm{K} \%$ by Foeniculum vulgare Mill. plants in the two growing seasons.

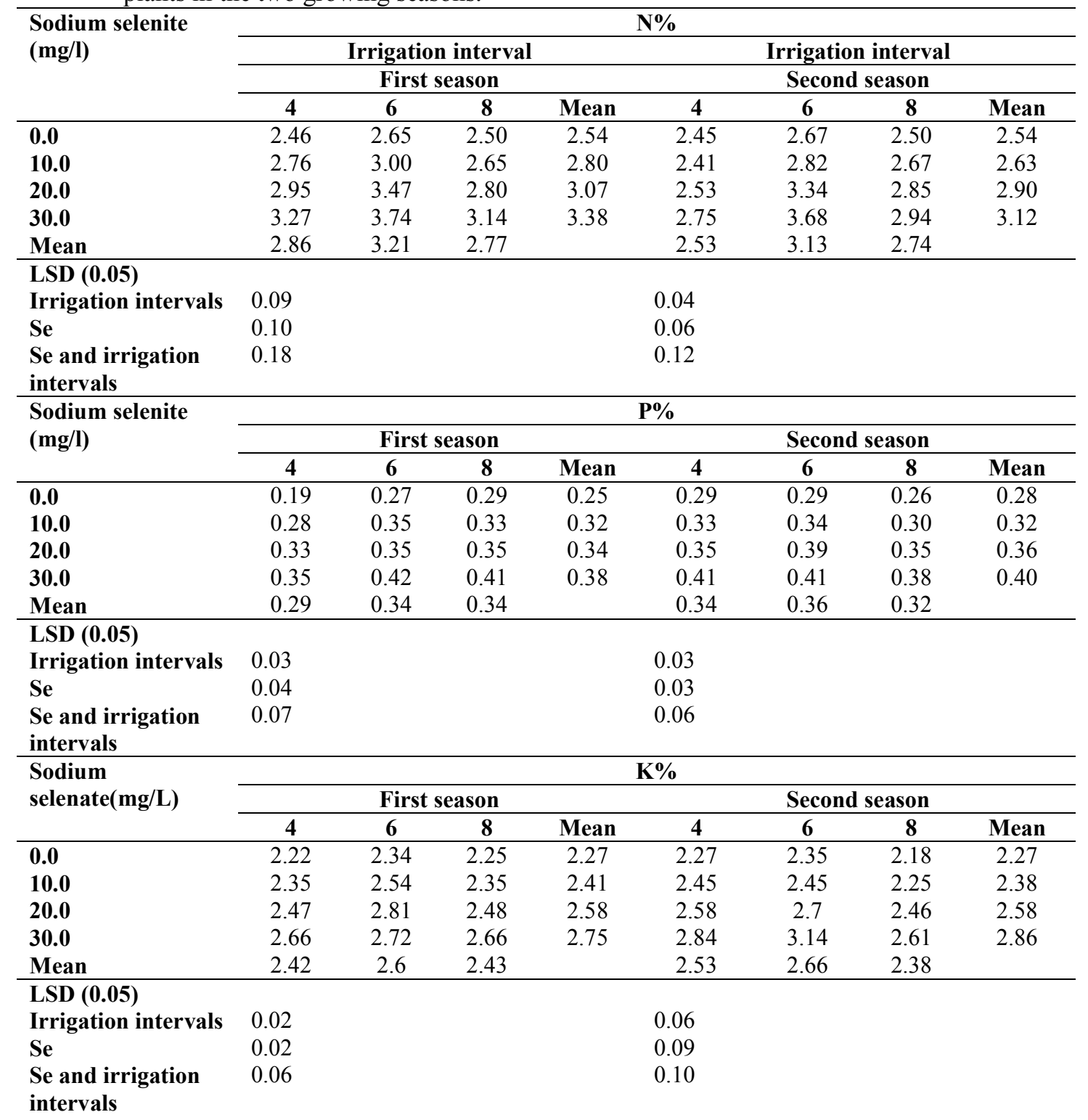

The study shows that, the importance of the effect of both irrigation rates and adding selenium to provide the amount of water used in irrigation every 6 days of the plant's consumption rate, which works to improve the growth and production of fennel plants under conditions of limited water.

Irrigation at 6 days resulted in increased growth and development attributes which significantly increased seed of fennel over irrigation at 4 and 8 days interval.

Although there is increasing evidence that Se enrichment of plants can exert beneficial effects on their growth, antioxidant capacity and stress tolerance (Hartikainen, 2005), Se however has not been 
recognised as an essential micronutrient for higher plants (Seppa"nen et al., 2010). The results of the present study demonstrated that an addition of Se to the nutrient exerted an effect on the growth of fennel plants depending on Se concentration.

Therefore, the results of this experiment indicate that the essential oil yield of fennel plants grown in this or similar areas can be increased by irrigation and by the application of selenium. Also, because an increase in percentage volatile oil with decreasing number of irrigations, compensates to some extent for decreasing growth and seed yield with decreasing irrigation, irrigation every six days can produce similar oil yields per plant.

\section{References}

A.O.A.C., 1970. Association Official Agricultural Chemists (1970) "Official Methods of Analysis". 9th Ed. The A.O.A.C. Washington D.C., U.S.A.

Anand, P., A. Kunnumakara, C. Sundaram, K. Harikumar, S. Tharakan, O. Lai, B. Sung, and B. Aggarwal, 2008. Cancer is a preventable disease that requires major lifestyle changes. Pharmaceut. Res., (25): 20-26.

Blanch, J.S., J. Penuelas, J. Sardans and J. Liusia, 2009. Drought, warming and soil fertilization effects on leaf volatile terpene concentrations in Pinus halepensis and a uercusilex. Acta Physiol Plant, 31: 207-218.

Boghdady, M.S., E.M. Desoky, S.N. Azoz, M. Dalia, and A. Nassar, 2017. Effect of selenium on growth, physiological aspects and productivity of faba bean (Vicia faba L.). Egypt. J. Agron., 39(1):83- 97.

British Pharmacopoeia, 1963. Determination of Volatile Oil in Drugs. The Pharmaceutical Press, London.

Brown, J.D. and O. Lilleland, 1946. Rapid determination of potassium and sodium in plant material and soil extracts by flame photometery. Proc. Amer. Soc. Hort. Sci., 48: 341-346.

Cioanca, O., M. Hancianu, C. Mircea, A. Trifan, and L. Hritcu, 2016. Essential oils from Apiaceae as valuable resources in neurological disorders: Foeniculum vulgare aetheroleum. Industrial Crops and Products, 88: 51-57.

Diao, W. R., Q.P. Hu, H. Zhang, and J.G. Xu, 2014. Chemical composition, antibacterial activity and mechanism of action of essential oil from seeds of fennel (Foeniculum vulgare Mill.). Food Control, 35(1): 109-116.

Hach, S., V. Brayton and B.K., Alan, 1985. A powerful Kjeldahl nitrogen method using peroxyanosul furic acid. J. Agric. Food Chem., 33: 1117-1120.

Hajiboland, R. and N. Keivanfar, 2012. Selenium supplementation stimulates vegetative and reproductive growth in canola (Brassica napus L.) plants. Acta Agric. Slov., 99: 13-19.

Hartikainen, H., 2005. Biogeochemistry of selenium and its impact on food chain quality and human health. J. Trace Elem Med Bio., 18: 309-318.

Letchamo, W., X.U. Hi, and A. Gosselin, 1995. Photosynthetic potential of Thymus vulgaris selection under 2 light regimes and 3 soil-water levels. Scientia Horticulturae, 62: 89-101.

Nassar, M.I., E.A. Aboutabl, Y.A. Makled, E.D.A. El-Khrisy, and A.F. Osman, 2010. Secondary metabolites and pharmacology of Foeniculum vulgare Mill. subsp. piperitum. Revista Latino americana De Química, 38(2):103-112.

Ormeno, E., J.P. Mevy, B. Vila, A. Bousquet-Melou, S. Greff, G. Bonin and C. Fernadez, 2007. Water deficit stress induces different monoterpene and sesquiterpene emission chages in Mediterranean species. Relationship between terpene emissions and plant water deficit. Potential. Chemosphere, 67: 276-284.

Page, A.L., R.H. Miller and D.R. Keeney, 1984. Methods of Soil Analysis. Part 2: Chemical and Microbiological Properties. Second edition. Agronomy J. 9: 2, Am. Soc. Agron. Inc., Soil Sci. Soc. Am. Inc. Pub. Madison, Wisconsin, USA.

Patel, A.U., B.S. Patel, K.P. Patel, I.D. Patel and M.I. Patel, 2000. Response of fennel (Foeniculum vulgare) to irrigation, nitrogen and phosphorus. Indian J. Agron., 45: 429-432.

Patel, B.S., K.P. Patel, I.D. Patel, and M. Patel, 2000. Response of fennel (Foeniculum vulgare) to irrigation, nitrogen and phosphorus. Indian Journal of Agronomy, 45: 429-432. 
Rhizopoulou, S. and S. Diamantoglou, 1991. Water stress induced diurnal-variations in leaf water relations, stomatal conductance, soluble sugars, lipids and essential oil content of Origanum maforanal. Journal of Horticultural Sciences, 66: 119-125.

Sangwan, N.S., A.H. Abd Farooqi, and R.S. Sangwan, 1994. Effect of drought stress on growth and essential oil metabolism in lemongrasses. New Phytologist, 128: 173-179.

Sangwan, R.S., A.H. Abd Farooqi, R.P. Bansal, and N.S. Sangwan, 1993. Interspecific variation in physiological and metabolic responses of five species of Cymbopogon to water stress. Journal of Plant Physiology, 142: 618-622.

Seppa"nen, M.M., J. Kontturi, I.L. Heras, Y. Madrid, C. Ca'mara, and H. Hartikainen , 2010. Agronomic biofortification of Brassica with selenium: enrichment of SeMet and its identification in Brassica seeds and meal. Plant Soil, 337:273-283.

Yadav, A.C., J.S. Yadav and O.P. Dhankhar, 2000. Effect of row and plant spacing on growth and yield of fennel (Foeniculum vulgare Mill.) cv. PF-35. In: Spices and Aromatic Plants-Challenges and Opportunities in the New Century. Contributory Papers -Centennial Conference on Spices and Aromatic Plants, Calicut, 20-23 September 2000 (199-201). Indian Institute of Spices Research, Calicut. 